\title{
Caddo Archives and Economies
}

\section{Paul S. Marceaux}

University of Texas at Austin

Follow this and additional works at: https://scholarworks.sfasu.edu/ita

Part of the American Material Culture Commons, Archaeological Anthropology Commons, Environmental Studies Commons, Other American Studies Commons, Other Arts and Humanities Commons, Other History of Art, Architecture, and Archaeology Commons, and the United States History Commons

Tell us how this article helped you.

This Article is brought to you for free and open access by the Center for Regional Heritage Research at SFA ScholarWorks. It has been accepted for inclusion in Index of Texas Archaeology: Open Access Gray Literature from the Lone Star State by an authorized editor of SFA ScholarWorks. For more information, please contact cdsscholarworks@sfasu.edu. 


\section{Caddo Archives and Economies}

Creative Commons License

(c) (i) (8)

This work is licensed under a Creative Commons Attribution-NonCommercial 4.0 International License 


\title{
Caddo Archives and Economies
}

\author{
Paul Shawn Marceaux \\ The University of Texas at Austin
}

Introduction

This article is a discussion of archival research on contact through historic period (ca. A.D. 1519 to 18 th century) Caddo groups in eastern Texas and west central Louisiana. First, I describe general objectives for current and long-term research on the Caddo Indians, followed by the central issues the article will address. A brief summary of protohistoric and historic events, actors, and sources will be followed by methodological considerations, as well as a discussion of Caddo economies, concluding with some reflections on Caddo archives and economies. This article explores the complex and interrelated economies of Native American and European populations during the colonization process in early Spanish Texas.

\section{Objectives}

My principal long-term goals are thorough cultural and archeological analysis of Caddo groups from the Late Caddoan period (ca. A.D. 1500) through their removal from Texas in 1859. In order to better understand the consequences of Native American and European contact, I will employ an interdisciplinary approach that utilizes previously excavated archeological data, information from ongoing archeological investigations, and archival records documenting the arrival and subsequent occupation of the area by Spanish and French military, missionaries, and traders.

I concentrate on information fleshed out from primary texts and translations of Spanish and French documents from initial contact to the mid-18th century. Subject matter focuses on the economic processes and material exchange that accompanied the arrival of European groups. Economic affairs of Caddo and European groups were negotiated through alliances, trade connections and interactions, marriage, and at times straightforward military might. The main goal of reviewing the archival records associated with Caddo groups is to reveal the events and processes of changing economic, political, and social systems of Native and European populations.

It is my contention that the archival material provides insight into the chaotic shifts and changes of the economies of both Caddo and European groups. I also believe it will be beneficial to further differentiate, when possible, between the colonial policies of the French and Spanish. For this reason, special attention is directed to interactions, transactions, and negotiations of Caddo groups with Spanish and French missionaries, soldiers, and government officials.

This research is designed to fill in crucial gaps in our knowledge of Caddo groups, especially fine-tuning our current understanding of their economic systems. Relevant research questions include:

- What is the nature of trade and exchange (economic interactions) between the Caddo and Europeans?

- What adaptive responses are the Caddo instituting to deal with the influx of European trade goods, a demographic collapse, and other effects of contact? 
- How are Europeans using Caddo political systems to control and manipulate the Caddo, and conversely how are the Caddo controlling and manipulating the Europeans?

- How are economic products such as horses, guns, animal skins, salt, and maize negotiated; in other words what are the (cultural) exchange rates?

\section{A Few Notes on Methodology}

The archival documents for this region and time are rich; however relatively little work has been done on the primary sources in recent years. The majority of studies have relied on 20 th century translations, which after a brief review are found to contain some discrepancies. I consulted both primary documents and reviewed translations in order to ensure accuracy in their content and meaning. With the assistance of Dr. Mariah Wade, at The University of Texas at Austin, primary documents that are especially relevant to the current study have been re-translated. The vast number of applicable archival sources precludes examination of the entire archival corpus. However, a manageable number of primary documents were consulted and the majority of secondary translations were reviewed.

The first step was to review translated archives for the protohistoric and early Historic periods. Many of these sources, especially those from the earliest missions, have been used by numerous scholars to elucidate the processes of Caddo cultural change. Secondly, primary sources, including Casañas (1927) and various items in Margry (1879), were re-translated (with translations at hand for comparison when available).

Finally, using examples from the archives I analyze and compare Caddo and European economies. In an attempt to maintain a semblance of chronology and continuity, events, actors, and interactions are placed in historical context. Of course, there are problems with continuity due to the inherent incompleteness of the historical record. Additionally, one must consider the potentially disjunctive effects of disease and population collapse (see Derrick and Wilson 2001; Dobyns 1983; Ewers 1973; Ramenofsky 1987) on Native American social, political, and economic systems.

The ostensibly cyclical founding and abandonment of Spanish missions serves as an example of the difficulties associated with establishing permanent European settlements among the Caddo Indians. The French example of La Salle's Fort St. Louis bears further witness. The site was on the receiving end of Native American attacks, likely by the Karankawa, and ended in the destruction of the site and the death of all but a handful of its occupants. What follows is an overview of the early sources on contact period Caddo groups occupying parts of eastern Texas and west central Louisiana.

\section{Protohistoric Period}

According to Perttula (2002), the Caddo protohistoric period, the time from earliest evidence of European contact to the start of detailed and continuous written records and sustained contact, extends from ca. 1520-1685. "Only the De Soto entrada in 1542 and the La Salle expedition in 1685 record actual face-to-face European contact with Caddo groups in this period" (Perttula 1992:95).

The De Soto entrada was the first Spanish expedition to make contact with Caddo groups (Table 1), and this occurred in the Caddo province of Naguatex on the Red River in August 1542 (Clayton et al. 1993). There

is significant evidence available for local and non-local trade; for example, Hudson (1997) notes that De Soto's 
expedition observed objects made of turquoise and cotton. indicating trade between the Guasco, a Caddo group on the Neches River in East Texas, and Southwestern groups. However brief, the De Soto chronicles provide insight into the geographic boundaries (Hudson 1997) and social organization (Perttula 2002) of Caddo contact period polities.

Table 1. Associated Spanish Expeditions, 1542-1778.

\begin{tabular}{ll}
\hline Expedition & Date \\
\hline De Soto-Moscoso & 1542 \\
Alonso de Leon & 1689 \\
Alonso de León and Fray Massanet & 1690 \\
Domingo Terán de los Ríos & $1691-1692$ \\
Gregorio de Salinas Varona & 1693 \\
Fray Isidro de Espinosa, Fray Antonio de Olivares and Pedro de Aguirre & 1709 \\
Domingo Ramón with Espinosa and St. Denis & 1716 \\
Martín de Alarcón & 1718 \\
Marqués de San Miguel de Aguayo & $1721-1722$ \\
Pedro de Rivera & 1776 \\
Marqués de Rubí & 1767 \\
Mézières, lieutenant governor of Natchitoches & 1772,1778 \\
\hline
\end{tabular}

Juan Sabeata provides an interesting 'case history' of a Native agent that appears in the historical record from 1683 to 1692 (Kelley 1955; Wade 2003). Sabeata and a number of Native delegates appear first in El Paso del Norte, now known as Ciudad Juarez, Chihuahua, Mexico. During the first two meetings (11 August and 20 October 1683), he relates to Spanish officials important information such as:

1) they want to reestablish the communication and friendship they had before, 2) [they] would profit and trade as they had always done, 3 ) that other Spaniards [actually the French] very white and with red hair came by the sea in wooden houses that walk on water, 4) ask for a friar in order that when they were ill he [the friar] could console them and when they died [they] would be buried as Christians and [the friar] would baptize the other people who are...over ten thousand souls, 5) ask for Spanish families in order that they will defend them against their enemies the Apaches, and 6) that Sabeata will guide them to the Texas (translations from Wade 2003: 236-240, brackets mine).

First-hand statements by Native individuals, although recorded by European actors, are regrettably uncommon. However, those that are known serve to illustrate the stated agendas and requests of Native groups. Notably, Sabeata mentions the Tejas on both visits relaying their "good lands and great production" and willingness to "receive the Spaniards and the Friars with great affection and love" (Wade 2003).

\section{Early Historic Period}

Although Rene-Robert Cavelier, Sieur de La Salle's expedition landed on the Texas coast in 1685 (Table 2), he did not depart on his first trip to the Cenis (Hasinai) villages until 28 April 1686. When La Salle visited 
the Hasinai on this trip, he purchased horses already owned by Caddo groups. This point is reinforced by Tonti, who in 1690 reported that horses were widely available (Swanton 1942).

La Salle's second trip to the Hasinai village was cut short when on 19 March 1687 he was assassinated by members of his own party. However, Henri Joutel (Foster 1998; Joutel 1906) continued to document the French experience, which included important details on the role of economic exchange. Joutel and his group arrived at the Hasinai villages on 30 March 1687 and stayed for almost three months. In this account, the Hasinai provided raw materials, and produced prepared (manufactured) goods, which were constantly negotiated for French trade items.

Table 2. Associated French Expeditions, 1685-1721.

\begin{tabular}{|ll|}
\hline Expedition & Date \\
\hline La Salle lands on Texas coast, founds Fort St. Louis & 1685 \\
La Salle first trip to Cenis & 1686 \\
Henri de Tonti & 1690 \\
Louis Juchereau de St. Denis & 1700,1705 \\
St. Denis, establish Fort St. Jean Baptiste aux Natchitos & 1714 \\
La Harpe and Du Rivage, establish trading post with Kadohadacho & 1719 \\
La Harpe, establish trading post among Wichita & 1721 \\
\hline
\end{tabular}

Henri de Tonti, founder of the Arkansas Post, descended the Mississippi River in 1690 to locate La Salle (Delangez 1944; Margry 1879). In search of the lost colony, on 17 February 1690 Tonti arrived in the Natchitoches area. While there, he helped arrange a treaty between the Natchitoches and Taensa.

Captain Alonso de León led two expeditions in 1689 and 1690 to locate La Salle's settlement on the central Texas coast. De León's 1690 expedition diary, Fray Damián Massanet's letter, and Juan Bautista Chapa's "Historia del Nuevo Reino Leon" (Chapa 1997; Massanet 1899) provide vital sources for Native American-Spanish relations in northeastern Mexico and into East Texas. While searching for two Frenchmen from Fort St. Louis, Captain De León and his expedition encountered a 'Tejas captain' on the Guadalupe River. This represents the first documented Spanish contact with the Caddo since the 1650 Martin-Castillo expedition (Wade 2003:74).

Captain De León did eventually locate La Salle's settlement, along with drifting Frenchmen, which prompted the first Spanish missions to be established among the Caddo. De León's expedition in 1690 was "arranged to explore the province of the Tejas" (Chapa 1997:143). On 22 May, the Spanish, accompanied by a "Tejas governor," crossed the Rio de la Santisima [Trinity River] into the beginning of the land of the Tejas (Chapa 1997). Here the Spanish noted numerous fields of corn, beans, pumpkins, and watermelon, and were hospitably treated to tamales. Alonso de León describes the community along the Neches River:

The principal settlement encompasses fourteen to fifteen leagues, but we were unable to see all of it because of a river that passes through the middle. In the part that we did see there were more than four thousand people (Hadley et al. 1997:323).

Captain Alonso de León and Fray Massanet established the first two Spanish missions, Mission San Francisco de los Tejas and Mission El Santisimo de Nombre Maria, among the Nabedache on the Neches River 
in 1690. An important question I attempt to address below is: during this first sustained contact, what are the particular historical circumstances and conditions surrounding the trade and negotiation of European and Caddo goods? In addition, what are the politico-economic strategies being employed by each side?

The expedition of Domingo Terán de los Ríos, sent to establish seven missions among the Tejas (see Table 1), provides us with one of the earliest (and most discussed) maps of a Nasoni Caddo village (Schambach et al. 1983). The map provides clues, through the eyes of the Spanish, about the physical landscape of Caddo settlements. Details of the map include the temple mound, still in use, and the location of the caddi's house. Although de los Rios was given a number of other tasks, including exploration of the lower Mississippi River, all of the missions he established among the Caddo ended in failure.

This first Spanish effort at colonization in the Caddo world resulted in continuous occupation until 1693. A great deal of information from this period is available, including the narratives of Fray Francisco Casañas de Jesus Maria, Juan Bautista Chapa, Captain Alonso de León, Fray Francisco Hidalgo, and Fray Damián Massanet (Bolton 1917, 1987; Casañas 1927; Castañeda 1936; Chapa 1997; De León 1690; Hidalgo 1927; Massanet 1899) and I will draw upon them to discuss the early Spanish missionizing experience in eastern Texas.

Louis Juchereau de St. Denis' exploration of the Red River in 1700 and 1705 led to the establishment of Fort St. Jean Baptiste aux Natchitos in 1714 (Habig 1984; Margry 1879). Although material and cultural exchange had long been initiated between the French and the Caddo, this represents the first permanent French establishment among the Caddo. Additional analysis of the role of this French settlement, including its particular association to the Natchitoches confederacy, will provide a comparative case for French and Spanish attempts at colonization.

The re-establishment of Spanish missions and towns, including San Miguel de Linares de los Adaes by Domingo Ramón in 1716-1717 and Presidio Nuestra Señora del Pilar de los Adaes by the Aguayo expedition in 1721, signaled the repeated effort to combat what the Spanish believed to be the infringement of French traders (Table 3). However, this did not dissuade the French from further advances, exemplified by the 1719 exploration of La Harpe and Du Rivage that founded a trading post with the Kadohadacho.

This back and forth characterizes the sporadic founding and abandonment of settlements (see Table 3). Three times between 1690 and 1773, the Spanish completely withdrew their missions from the area. Shortly after the French ceded Louisiana to Spain in 1767, all Spanish missions in the provinces of Texas and Louisiana were abandoned. The narratives of La Salle, Joutel, St. Denis, and Henri de Tonti (Delangez 1944; Foster 1998; Habig 1984; Joutel 1906; Margry 1879) will be used to discuss the early French experience in the study area.

\section{Caddo Economies}

During the protohistoric period, the discontinuity of documents makes it difficult to clarify the exact changes affecting Caddo economies. It is in these gaps that archeology can best be used to supplement historic records. Up to this point I have relied on previous excavations to complement archival records. In order to address the incompleteness of this period, in the future 1 hope to organize additional archeological research on Caddo sites dating to the protohistoric period.

The first exposure to goods such as guns, metal implements, horses, and cloth, undoubtedly had an impact on Native economic systems. Two noteworthy examples include: (1) the change from using wooden or bison scapula hoes to those manufactured from metal; and (2) the switch from stone tool technology for knives and 
Table 3. Founding and Abandonment of European Settlements.

\section{Event Date}

First two Spanish missions, Mission San Francisco de los Tejas and

Mission El Santisimo de Nombre Maria, established

Spanish missions withdrawn

First French outpost, Fort St. Jean Baptiste aux Natchitos, established

Missions Nuestra Padre San Francisco de Tejas, Purisima Concepcion,

San Jose de Nazones, Nuestra Senora de los Nacogdoches, Nuestra Senora

Dolores de Ais, and San Miguel de los Linares de los Adaes, and Presidio

Nuestra Senora de los Dolores de los Tejas founded.

Spanish missions and presidios withdrawn

Missions Nuestra Padre San Francisco de Tejas, Purisima Concepcion,

San Jose de Nazones, Nuestra Senora de los Nacogdoches, Nuestra Senora

Dolores de Ais, and San Miguel de los Linares de los Adaes, and Presidios

Nuestra Senora de los Dolores de los Tejas, and Nuestra Senora del Pilar

de los Adaes (re)founded.

Mission Purisima Concepcion abandoned

Missions Nuestra Padre San Francisco de Tejas and San Jose de Nazones,

and Presidio Nuestra Senora de los Dolores de los Tejas abandoned.

French cede Louisiana to Spain

All Spanish missions abandoned in provinces of Texas and Louisiana

scraping tools to metal goods such as knives and reused gun parts. Carlson and Corbin (1999:54) note that the small number of lithic tools at Mission Dolores de los Ais, including arrow points, may point to the replacement of "stone tools with ones of metal manufacture." In return, Caddo groups provided raw materials, such as salt, bois d'arc, food items, and processed goods such as maize, skins and furs, and ceramics. Although early European expeditions were well equipped, without Native manufactured goods, local raw materials, and the cultural knowledge and insight of Native groups, many would have failed miserably.

According to Wyckoff and Baugh (1980:229), the Hasinai economy was based on four basic subsistence activities: farming, hunting, collecting, and fishing. Horticulture and the production of maize was a major component of the subsistence economy, although Caddo groups were by no means reliant on agricultural products. This subsistence-based agricultural society, whose economy was based on goods necessary for basic needs, relied on a diversified food production system.

Both the Hasinai and Natchitoches confederacies, although more aptly termed kin-based alliances of tribes, were in existence by ca. 1690 (Pertula 1993). The Hasinai confederacy occupied the upper reaches of the Neches and Angelina river valleys in East Texas, while the Natchitoches confederacy occupied the Red River near the French post of Natchitoches in west-central Louisiana. According to Casañas (1927), the Hasinai confederacy 
consisted of nine principal tribes, including the Cachae, Nabadacho, Nabiti, Nacachau, Nacono, Nasayaha, Nazadachotzi, Necha, and Nechavi. These allied groups, consisting of approximately 3500 people (Smith 1998), are well-known from a variety of historical and ethnohistorical studies (Bolton 1914, 1987; Espinosa 1927; Griffith 1954; Hickerson 1992; Kress and Hatcher 1932; Newkumet and Meredith 1988; Wyckoff and Baugh 1980). The Natchitoches confederacy consisted of at least three tribes, including the Yatasi, Doustioni, and lower Natchitoches (Smith 1998). Although the exact nature of these confederacies needs further attention, it is clear from the archival record that these groups maintained distinct affiliations.

It is difficult, if not impossible, to gauge whether the Spanish had a greater impact on the Hasinai confederacy, or conversely, the French had greater influence on the Natchitoches confederacy. Questions such as the impact of European contact on particular groups can only be addressed when placed in a specific historical context. What is apparent is that both the confederacies and Europeans were engaged in exploitation and compromise, with each group working towards their own best interests.

Juan Sabeata, a Jumano leader asserting political relations with the Caddo, requested friars, Spanish settlers, and military personnel to battle the Apache, on a promise to aide the Spanish in return. Unfortunately, he is one of the only examples I found of a named Native American agent appealing for and engaging in material and ideological exchange. His pleas came at an opportune time for Spanish authorities seeking to: (1) keep the peace in El Paso; (2) acquire more military supplies; (3) appease the friars; (4) obtain food and furs desperately needed by colonists; and (5) and scout potential new areas for settlement (Wade 2003:77). The Mendoza-López expedition that was to follow Sabeata's request was made even more attractive, considering that the Pueblo revolts of 1680 in New Mexico were preventing Spanish from maintaining settlements in that area.

During his address to the Governor, Sabeata offered the Spanish food and material incentives such as pearls, deer gamusas, shoes, and buffalo skins. He also indicated that the Tejas have many horses, of which they feed corn because "they have many herds of mares which they have raised" (Wade 2003:239) His ability to corroborate several events involving the Spanish and his more fanciful tales of crosses "falling from the sky" confirms his understanding and skill at diplomacy. Sabeata, and individuals like him, played a vital role in the material and communication exchange network between the Caddo in East Texas, the Spanish in New Mexico, and associated mobile groups occupying areas in between the two.

During the La Salle expedition, individual transactions in the form of amounts and descriptions of goods provide eventful facts of trade and exchange. On La Salle's last journey, from Fort St. Louis to the Brazos River, the French were decidedly dependent on Native guides in order to successfully navigate the local landscape (Foster 1998). Joutel, for example, tells us that a hatchet was offered by La Salle in exchange for a Native American guide to lead them to the place where he (La Salle) had left a stash of corn and beans (Foster 1998:194). There is a tit-for-tat rhythm to the needs and payment of services and material goods. This is not to say that the hatchet was an especially expensive item for the French, but for the hungry French there was little option. Just after La Salle's death, right before entering the Cenis village, Joutel in effect admits that the French are reliant on the Caddo for food and other necessities. He even retells the crossing of the large stream, where the Natives could have easily left several Frenchmen to their death, returning afterward to collect the booty (Foster 1998:200).

Upon Joutel's approach into the villages of the Cenis, they were surprised by the presence of a Caddo dressed in Spanish clothing. They were also informed that residing in a near-by village were "one and two others ... in a place called Sapony [Nasoni?]." These individuals were actually French deserters from Fort St. Louis. At this point, three years before the Spanish founded their first two missions, Joutel notes: 
seven or eight of them [Caddos from the Nabedache village] had sword blades with clusters of feathers on the hilt. These blades were squared like those of the Spaniards; they also had several large bells...a few of them also had some piece of blue material which they must have obtained from the Spaniards [brackets my own] (Foster 1998:205).

Joutel's journal while among the Cenis is an informative record of two knives here, and a bell and some trinkets there. Most interactions that the Frenchman noted were accompanied by material exchange of some sort. On several occasions, once by a "respected elder," Joutel is offered a wife/female, an event that demonstrates further the efforts of the Caddo to build relationships and/or alliances between the two groups. Using the social institution of marriage, the Caddo were deliberately extending fictive kin alliances between themselves and the French.

Noting the Cenis' affinity for, and yet lack of, knives and hatchets, Joutel declared this as proof that "the Spaniards had not given them much" (Foster 1998:210). This statement supports the notable differences in Spanish and French strategies and methods of material distribution, the French being 'traders' and 'mercantilists' and the Spaniards primary concerns lay elsewhere (Perttula 1992; Wade 1989). The subtlety of the Spanish approach (and underlying motives) can be surmised in Casañas' section of text that moves from a description of material goods the Caddo utilized to the statement "how wise it would be to provide these poor creatures with the abovementioned items" (Casañas 1927:285).

According to Chapa (1997), the first meeting in the principal Nabedache village was full of pomp and pageantry, including a procession of Spanish priests and officers. It also resulted in the Spanish constructing a chapel, and three priests were left behind to manage the souls of the Tejas. When De León and Fray Massanet requested that more than three soldiers remain, the Caddo chief refused. A certain measure of influence can be gleamed from this refusal; that the Spanish complied is something of an exception. The Caddo insisted that no more than six men, three priests and three soldiers, remain for fear that the Spanish would "appropriate the Indians' women" (Chapa 1997:151). This assertion of power stands in contrast to the strategy of extending fictive kin alliances, demonstrating the importance of context and situation.

In Chapa's accounts, Native American-Spanish interactions took on various forms with mixed results depending on the circumstance. Numerous encounters began with Natives scurrying into the countryside or mountains, only to be coaxed out later with gifts (Chapa 1997). In these instances, pacification (or ingratiation as the Spanish refer to it) of Native Americans was accomplished through the material exchange of clothing, food, knives, tobacco, and jewelry. It is unclear whether Caddo groups were among those to "flee the scene."

Casañas noted that there were so many vines, and fruit-producing plants, it looked as if they had been planted by hand (Casañas 1927:210). The agricultural success of the Caddo comes as no surprise considering they had been involved in farming practices for some 700 years or more before the Spanish or French ever arrived. Another interesting note is that in May 1690 the de León expedition notes that watermelons were being grown, a food source not native to the area. Caddo local experience and knowledge likely expedited the practice of cultivating foreign agricultural goods.

The law of supply and demand dictated the scale of social and political interaction. In my opinion, a closer examination of the inventory of European goods being distributed to the Caddo at particular points in time in the context of the Spanish mission/presidio system versus the French focus on mercantilism would support this.

Two unambiguous examples of the differences in Spanish and French policies are: first, in 1722, along with multiple missions, the Spanish occupied two presidios on the eastern border with France, one on the coast, and 
one in the interior. France, on the other hand, at this time had only two military posts, one with a garrison and one with a fort. However, it is also likely the French had several 'unofficial' trading villages (Gilmore 1992). Second, in a list of 26 suggestions and proposals for projects related to the settlement of this area, "friars for ecclesiastical purposes" was relegated to no. 22 (Margry 1879, Vol. 4: 40). The first 21 suggestions indicate that the French were much more interested in securing commerce, and building companies that would set up trade. Companies involved in commerce were in charge of equipping and arming, organizing the settlers, and providing jobs. Many of these functions were organized by the Spanish crown, with its explicit ecclesiastical objectives, and not led by commercial companies.

Around the beginning of the 18 th century as the Spanish abandoned their first mission attempts, we see the French sending several expeditions to visit the Hasinai tribes, developing and engaging in trade relations (Swanton 1942). In a letter from Sieur Argoud, a friend of La Salle, to the Marine Minister it is stated, "there is no need for the French to carry cash, Natives would rather knick-knacks" (Margry 1879, Vol. 4:24). According to Perttula (1992:35), there was no material dependence by the Caddo on Spanish goods because the French were so successful in promoting trade. However, the horse was an invaluable commodity that may be an exception. A caveat to this would be that the Caddo were likely getting many of their horses from other Native groups and not directly from the Spanish.

As further evidence of early European interaction, Cadillac, the French commander in Louisiana, received a letter from Fray Hidalgo asking the French for assistance. This letter, encouraging French and Spanish coordination, directly contradicted Spanish colonial policy. One response to this letter was the trip of St. Denis from Natchitoches across northern New Spain and eventually to Mexico City (Shelby 1923) where he was detained.

The Spanish were aware of French ventures, indicated by Casañas' list of goods and "ornaments they have secured from other nations" (Casañas 1927). And conversely, the French were aware of the Spanish, an example being the meeting between Joutel and the Hasinai where the Native chiefs were adorned with Spanish goods (Foster 1998). Ethnohistoric and archeological evidence supports the acquisition, trade, and exchange of European and non-local objects as one of the many priorities of ruling elites and other members of the Caddo Nation.

The introduction of the Caddo Area into the world economy (Braudel 1984; Wallerstein 1974-1980; Wolf 1982 ) is a significant event that requires more attention. The rate at which Caddo groups were introduced and integrated into that economy varied. Although early Spanish policies were to restrict French trade, they were unable to provide enough supplies to satisfy Native requests. "These nations say: the Spaniards offer fair words; the French fair words and presents" (Hackett 1931-1946). One factor influencing provisions was the difference in supply lines between those originating in northern New Spain and those originating in New Orleans (Bolton 1914). For example, the post of Natchitoches was approximately 130 leagues ( 338 miles) from New Orleans and there was a good road between Los Adaes and Natchitoches. The Spanish, on the other hand, were forced to bring merchandise over 600 leagues ( 1560 miles) over land, a very expensive endeavor.

\section{Reflections}

The economic goods utilized, traded, and consumed by Native and European populations included maize, skins and furs, bois d'arc, salt, horses, guns, pearls, ceramics, and other raw materials. The mechanisms and varying components of food production systems, agricultural economies, trading strategies, hunting and gather- 
ing activities (and the accompanying territorial issues), as well as land-use and management, are all significant issues that need further sorting out.

Many of the Spanish accounts reffect the religious fervor and bias that frequently accompany colonial projects, but there is an underlying substance useful for anthropological study. European military attention to (1) Natives' calls to war, (2) outside threats from Apache tribes, and (3) local uprisings are indicative of the resistance Native Indian groups were capable of. Although Spanish equipment used in warfare was superior, Native's knowledge and use of the landscape provided advantages. Chapa (1997) notes the frequent practice of abandonment of camps, as well as the hiding from and evading Spanish forces. In addition, without the help of Natives guides, many Spanish expeditions would have been painfully unsuccessful.

An interesting example of social exchange, the Caddo adoption of Spanish religious practices, was witnessed by De León (Chapa 1997:136). Apparently, a shrine was set up by the first Tejas captain they met. Though at this time no permanent Spanish settlement had been established, a Tejas captain on the Guadalupe River (many miles from their principal villages), camped with two Frenchmen from Fort. St. Louis, was utilizing Christian ideological symbols. Chapa specifically recalled one night that the Tejas captain replied in response to the question "had he or his ancestors seen a woman wearing a habit":

He had not seen her, but ...he had heard of such a person from his ancestors...on some occasions a lady wearing the habit they showed him had appeared to his ancestors (Chapa 1997:138).

Whether these statements are accurate, a fabrication to maintain Spanish attention, or distorted missionary zeal; what is certain is that the Tejas captain used Christian ideology in order to gain further access to Spanish goods.

Further investigation of the archeological material remains will add to the wealth of information from the historical sources of Spanish and French explorers. It has been shown here that the archives provide unique insights into the economic and social exchange of these contact period Caddo groups. Due to the influx of European trade goods, and the introduction of disease and population decline that followed, Caddo groups that occupied eastern Texas and Louisiana experienced major changes in political, economic, ideological, and social organization.

It is hoped that in the future, archives from the mid-18th century through the removal period will be reevaluated, with special consideration given to those previously receiving little attention. This will require the translation of archival sources tangential to expeditions and settlements, further concentrating on economic relationships and interactions between the Caddo and Europeans, as these would add to the current study. In conclusion, this article represents a scratch on the surface of possibilities that the archives provide. I have learned that the archives are packed with examples of material and social interactions of contact period Native American groups, like the Caddo, and Europeans.

\section{References Cited}

Bolton, Herbert E.

1914 (Ed.) Athanase de Mezieres and the Louisiana-Texas Frontier, 1768-1780. Vols. I and 2. Clark Publishing, Cleveland.

1917 The mission as a frontier system in the Spanish-American colonies. American Historical Review 23:42-61.

1987 The Hasinais, southern Caddoans as seen by the earliest Europeans. University of Oklahoma Press, Norman. 
Braudel, F.

1984 Civilization and Capitalism, 15th--18th Century, Volume III: The Perspective of the World. Harper and Row, New York.

Carlson, Shawn B. and James E. Corbin

1999 Mission Dolores Reivisted. Bulletin of the Texas Archeological Society 70:49-57.

Casañas, Fray Francisco

1927 Descriptions of the Tejas or Asinai Indians, 1691-1722. Part I \& II. Southwestern Historical Quarterly:206-218, 283304.

Castañeda, C. E.

1936 Our Catholic Heritage in Texas. 6 Vols. Von Boeckmann-Jones Co, Austin.

Chapa, J. B.

1997 Texas and Northeastern Mexico, 1630-1690. Translated by Ned F. Brierly and edited by W. C. Foster. University of Texas Press, Austin.

Clayton, Lawrence A., Vernon J. Knight, and Edward C. Moore (editors)

1993 The De Soto chronicles: The expedition of Hernando de Soto to North America in 1539-1543. 2 vols. University of Alabama Press, Tuscaloosa.

Delangez, $J$.

1944 The Voyages of Tonti in North America. Mid-America 26:255-297.

Derrick, S. M. and D. E. Wilson

2001 The Effects of Epidemic Disease on Caddo Demographic Structure. Bulletin of the Texas Archeological Society 72:91103.

Dobyns, H. F.

1983 Their Number Become Thinned: Native American Population Dynamics in eastern North America. University of Tennessee Press, Knoxville.

Espinosa, Fray Isidro Felís de

1927 Descriptions of the Tejas or Asinai Indians, 1691-1722. Part IV. Translated from the Spanish by Mattie Austin Hatcher. Southwestern Historical Quarterly 31:150-180.

Ewers, J. C.

1973 The Influence of Epidemics on the Indian Populations and Cultures of Texas. Plains Anthropologist 18:104-115.

Foster, William C. (editor)

1998 The La Salle Expedition to Texas: The Joumal of Henr Joutel, 1684-1687. Texas State Historical Association, Austin.

Gilmore, $\mathrm{K}$.

1992 French, Spanish, and Indian Interaction in Colonial Texas. Bulletin of the Texas Archeological Society 63:123-133.

Griffith, W.J.

1954 The Hasinai Indians of East Texas as Seen by Europeans, 1687-1772. Middle American Research Institute, Tulane University.

Habig, M.

1984 Spanish Texas pilgrimage; The old Franciscan missions and other Spanish settlements of Texas, 1632-1821. Franciscan Herald Press, Chicago.

Hackett, C. W. (editor and translator)

1931-1946 Pichardo's Treatise on the Limits of Louisiana and Texas 4 Vols. University of Texas Press, Austin.

Hadley, D., T. H. Naylor, and M.K. Schuetz-Miller (editors)

1997 The Presidio and Militia on the Northern Frontier of New Spain: A Documentary History, Vol. 2, Part 2: The Central Corridor and the Texas Corridor, 1700-1765. University of Arizona Press, Tueson. 
Hickerson, Daniel A.

1992 Early Historic Hasinai Leadership: Toward a Coalition Theory. Cadđoan Archeology Newsletter III(2):1-11.

Hidalgo, Fray Francisco

1927 Descriptions of the Tejas or Asinai Indians, 1691-1722. Part II. Southwestern Historical Quarterly 31:50-62.

Hudson, C.

1997 Knights of Spain, Warriors of the Sun. University of Georgia Press, Athens.

Joutel, $\mathrm{H}$.

1906 An Historical Journal of the Late Monsieur de LaSalle's Last Voyage into North America to Discover the River Mississippi, H. R. Stiles, general editor. Joseph McDonough, New York.

Kelley, J. Charles

1955 Juan Sabeata and Diffusion in Aboriginal Texas. American Anthropologist 57 (5):981-995.

Kress, M. K. and M. A. Hatcher

1932 Diary of a Visit of Inspection of the Texas Missions Made by Fray Gaspar Jose de Solis in the Year 1767-1768. Southwestern Historical Quarterly 35:28-76.

Margry, Pierre

1879 Decouvertes et etablissements des Francais dans l'ouest et dans le sud de l'Amerique Septentrionale, 1614-1754. 6 vols., Paris.

Massanet, Damian

1899 Descubrimiento de la Bahía del Espíritu Santo (Discovery of the Bay of Espiritu Santo). Texas State Historical Association Quarterly Vol. II No. 4.

Newkumet, Vynola Beaver and Howard L. Meredith

1988 Hasinai : a traditional history of the Caddo Confederacy. Texas A\&M University Press, College Station.

Perttula, Timothy $\mathrm{K}$.

1992 "The Caddo Nation": Archaeological \& Ethnohistoric Perspectives. University of Texas Press, Austin.

1993 Kee-Oh-Na-Wah'-Wah: The Effects of European Contact on the Caddoan Indians of Texas, Louisiana, Arkansas and Oklahoma. In Ethnohistory and Archaeology: Approaches to Postcontact Change in the Americas, edited by J. D. Rogers and S. M. Wilson, pp. 89-109. Plenum Press, New York.

2002 Caddoan Area Protohistory and Archaeology. In Between Contact and Colonies: Archaeological Perspectives on the Protohistoric Southeast, edited by Cameron B. Wesson and Mark A. Rees, pp. 49-66. University of Alabama Press, Tuscaloosa.

Ramenofsky, A. F.

1987 Vectors of Death: The Archaeology of European Contact. University of New Mexico Press, Albuquerque.

Schambach, Frank F., Neal L. Trubowitz, Frank Rackerby, E. Thomas Hemmings, W. Fred Limp, and John E. Miller III

1983 Test Excavations at the Cedar Grove Site (3LA97): A Late Caddo Farmstead in the Great Bend Region, Southwest Arkansas. In Contributions to the Archeology of the Great Bend Region, edited by Frank F. Schambach and Frank Rackerby, pp. 90-127. Research Series No. 22. Arkansas Archeological Survey, Fayetteville.

Shelby, C. C

1923 St. Denis's Declaration Concerning Texas in 1717. Southwestern Historical Quarterly 26(3):165.183.

Smith, F. Todd

1998 The Political History of the Caddo Indians, 1686-1874. In The Native History of the Caddo: Their Place in Southeastern Archeology and Ethnohistory, edited by Timothy K. Pertula and James E. Bruseth, pp. 175 181. Sudies in Archeology

30. Texas Archeological Research Laboratory. The University of Texas at Austin.

Swanton, John R.

1942 Source Material on the History and Ethnology of the Caddo Indians. Bulletin 132. Bureau of American Ethnology. Smithsonian Institution, Washington, D.C. 
Wade, Mason

1989 French Indian Policies. In Handbook of North American Indians, Volume 4, History of Indian-White Relations, edited by W. B. Washburn, pp. 20-28. Smithsonian Institution, Washington, D.C.

Wade, Mariah F.

2003 The Native Americans of the Texas Edwards Plateau, 1582-1799. University of Texas Press, Austin.

Wallerstein, I

1974-1980 The modem world system. 2 Vols. Academic Press, New York.

Wolf, Eric R.

1982 Europe and the people without history. University of California Press, Berkeley.

Wyckoff, Don G. and Timothy G. Baugh

1980 Early Historic Hasinai Elites: A Model for the Material Culture of Governing Elites. Midcontinental Journal of Archaeology $5: 225-283$ 